\title{
Nursery and Field Response of Olive Trees Inoculated with Two Arbuscular Mycorrhizal Fungi, Glomus intraradices and Glomus mosseae
}

\author{
Victoria Estaún, Amelia Camprubí, and Cinta Calvet \\ Institut de Recerca i Tecnologia Agroalimentàries (IRTA). Departament de Protecció Vegetal, Centre \\ de Cabrils, Crtra de Cabrils s/n, 08348 Cabrils, Barcelona, Spain \\ Jorge Pinochet \\ Agromillora Catalana S.A. El Rebato s/n, 08739 Subirats, Barcelona, Spain
}

\begin{abstract}
ADDITIONAL INDEX WORDS. endomycorrhizas, Olea europaea, isolate specificity, field inoculation, nursery inoculation, soilless substrates, yield response

ABstRact. This paper reports the effects of inoculation with arbuscular mycorrhizal fungi on early plant development, field establishment, and crop yield of the olive (Olea europaea L.) cultivar Arbequina. The response of olive plants to the fungi Glomus intraradices (Schenck and Smith) and G. mosseae (Nicol.\& Gerd.) Gerdemann \& Trappe in different potting mixes was studied in two different nursery experiments. Pre-inoculation with selected arbuscular mycorrhizal fungi prior to transplanting in the field improved plant growth and crop yield up to three years after inoculation. $G$. intraradices was more efficient at promoting plant growth than both $G$. mosseae and the native endophytes present in the orchard soil. Inoculation at the time of transplanting enhanced early plant growth in all the field situations studied. Diminishing mycorrhizal effects over time resulted from natural colonization of noninoculated seedlings and related to the native arbuscular mycorrhizal (AM) fungal population of the field soil. Early inoculation of olive seedlings enhances early plant development and crop productivity of olive trees.
\end{abstract}

There are multiple examples of plant growth being influenced by the arbuscular mycorrhizal (AM) symbiosis, however, many of the effects of AM fungi (AMF) have been studied in controlled experiments consisting of a host plant and a preselected AM fungal isolate grown in sterilized soil (Mosse, 1962; Smith et al., 1986). The positive plant response to the symbiosis has led to many attempts to manage or introduce AM fungi for increased crop production. In many cases experiments have been done with annual crops, and results have varied depending on previous soil treatments, AM fungal isolate, plant cultivar responsiveness to the AM symbiosis and fertilization patterns (Duffy and Cassells, 2000; McGonigle, 1988). These factors have in some instances superseded the effect of the mycorrhizal treatments. Mycorrhizal fungi have been proven to be vital agents for the growth of many fruit trees (Ba et al., 2000) including citrus (Camprubí and Calvet, 1996; Graham, 1986) and stone fruit trees (Estaún et al., 1999). However, there are few studies reporting the effects of controlled pre-inoculation on long-term tree growth. The objective of our study was to assess the results of inoculation with AMF in olive (Olea europaea L.) tree establishment and growth, both in the nursery and in the field. Olives have been traditionally grown around the Mediterranean. Spain is the main grower with over $2,000,000$ ha dedicated to this crop. Due to an increased awareness of the health benefits of olive oil, the area where the crop is grown is expanding in many countries. New olive groves for intensive oil production are increasing the area dedicated to this crop in Spain. Despite the use of locally adapted varieties, new or replanted orchards are progressively being planted with one of the following three cultivars: Picual, Hojiblanca and Arbequina.

Received for publication 3 June 2002. Accepted for publication 21 Apr. 2003. The authors wish to thank Agromillora Catalana S.A and FRUTESA for their help in conducting the experiments on which this manuscript is based. The authors also thank George Fernandez from the University of Nevada for statistical advise. The research was supported by grant no 95-0141-OP from the CICyT (Ministerio de Ciencia y Tecnología)
Another consideration is that olive trees are adapted to grow in poor edaphoclimatic conditions, with low nutrient inputs compared to other crops. Furthermore the cultivation of mycorrhizal olive trees can represent an alternative for a productive restoration of eroded and semi-arid areas.

\section{Materials and Methods}

The olive cultivar Arbequina was chosen for this experimentation because of the availability of high quality rooted cuttings, low vigor, resistance to cold winter temperatures and tolerance to several diseases. 'Arbequina' olive nursery trees are reproduced from leafy cuttings, which are rooted in a soilless substrate under greenhouse conditions with intermittent water mist. Rooted cuttings are then moved to individual pots and kept under greenhouse conditions.

To assess the effect of AMF on the early growth of the 'Arbequina' olive tree, two nursery experiments were conducted. The first was aimed at establishing the mycorrhizal symbiosis, and assessing its effects. The second experiment was done to simulate most of the conditions and constraints that would be found in a commercial operation.

Olive nursery trees are commonly sold as canned or balled stock. These trees are removed from the greenhouse, repotted in larger containers or bags and hardened, at ambient temperatures, outside, under lath, before being ready for field transplant. Alternatively, younger trees can be set in the orchard directly from the greenhouse if the edaphoclimatic conditions are adequate. Two field plantations, each one associated with one of the planting systems, were established to evaluate the feasibility and long term efficacy of artificial inoculation with selected AMF.

The selected fungi were Glomus mosseae BEG116 (Nicol.\& Gerd.) Gerdemann \& Trappe and G. intraradices BEG72 (Schenck and Smith), $(\mathrm{BEG}=$ The international Bank for the Glomales (www.ukc.ac.uk/bio/beg). Both isolates have been shown to 
promote plant growth (Dolcet-Sanjuan et al.,1996; Estaún et al., 1999), however, to our knowledge, no experiments with AMF inoculated olive trees in the field have been reported.

The inocula used in the experiments was produced with leeks as host plants. Quantitative standardization of the two fungal inoculants was not done due to the inherent diversity of the fungi used. Prestudy quality control of the batches of inocula used gave the following propagules/10g of soil: $G$. intraradices $=1100 \pm$ 300 and $G$. mosseae $=800 \pm 200$.

The plants used for all the experiments reported were obtained from Agromillora Catalana S.A. a commercial nursery. For nursery experiments 1 and 2, and field experiment 1, the plants used were 3 -month-old rooted cuttings in containers of $100 \mathrm{~mL}$, with an average height of $32 \pm 0.7 \mathrm{~cm}$ (mean \pm SEM of 50 plants chosen at random). Plants for field experiment 2 were 6-month-old rooted cuttings in $300 \mathrm{~mL}$ containers, with an average height of $76 \pm 1.1$ $\mathrm{cm}$ (mean \pm SEM of 50 plants chosen at random).

NuRSERY EXPERIMENT 1. This experiment was established to assess the infectivity of two AM fungal species. Rooted cuttings of 'Arbequina' olive were inoculated, or not, with a soil inoculum of G. mosseae or G. intraradices, according to the treatment. The inocula comprised rhizosphere soils and roots from leek (Allium porrum L.) pot cultures. There were 10 plants per treatment. The amount of inocula used was $20 \mathrm{~g}$ per plant placed directly below the plant roots. The growing medium was a pasteurized sandy soil, quartz sand, and sphagnum peat (Floratorf Floraguard $\mathrm{GmbH}$ ) mixture in a proportion of $3: 2: 1(\mathrm{v} / \mathrm{v})$. The resulting texture of the mix had $76 \%$ sand, $14 \%$ silt and $1 \%$ clay. The $\mathrm{pH}$ was 7.5 , with $1 \%$ organic matter and a CEC below $10 \mathrm{meq} / 100 \mathrm{~g}$. After 10 months growth in greenhouse conditions the plants were transplanted from 1- to 5-L containers, with the same potting mixture. The plants were then transferred to a microplot set up (Barker 1985) in an open shade house. Two and 10 months after inoculation the length of all shoots was measured and recorded as total plant growth. At 15, 17, 20, and 24 months after the inoculation the maximum plant height was measured. At 24 months the plants were harvested and the dry weights of stems and roots were measured. The roots were sampled and stained with $0.05 \%$ trypan blue in lactic acid (Phillips and Hayman, 1970) modified by the procedure described by Koske and Gemma (1989). The percentage of root colonization by AMF was determined using a grid-line intersect method (Giovannetti and Mosse, 1980). Data on plant growth were analyzed by ANOVA and plant height, measured at 2, 9, 15,20 , and 24 months after the plants inoculation was studied using a repeated measures analysis of variance (Systat). Data on percentage root colonization by AMF were arcsine transformed for analysis. When applicable, means were compared by using Tukey's test $(P \leq 0.05)$ (StatGraphicsPlus)

NuRSERY EXPERIMENT 2. The second nursery experiment was done to simulate the conditions likely to occur in commercial operations. The substrate chosen was a sphagnum peat (VAPO-XL), commonly used in nurseries. The plants were, as before, rooted cuttings of the olive cultivar Arbequina. The inoculum was delivered as alginate films as described by Calvet et al. (1996). The final concentration of spores was: $58 \pm 12$ spores per film for $G$. mosseae and $448 \pm 56$ spores for $G$. intraradices. Films with both fungi contained half the number of spores of each fungus. One-liter containers were used for the experiment and one alginate film was used per plant as inoculum of AMF. The film was placed below the plant's root system. There were 10 plants per treatment. The treatments were inoculated with $G$. intraradices, inoculated with $G$. mosseae, inoculated with $G$. mosseae plus $G$. intraradices, non inoculated, and non inoculated amended with $\mathrm{P}$

After the first month growth, all plants were routinely fertilized once a week with $100 \mathrm{~mL}$ per plant of a Hoagland and Arnon (1950) solution, minus phosphate, except the plants from the $\mathrm{P}$ fertilization treatment that received $100 \mathrm{~mL}$ of the full strength solution.

Four months after inoculation and transplant the total growth and the maximum height were measured. After 15 months growth the plants were harvested and the maximum height and the stem diameter were recorded. The percentage root colonization and plant growth were measured and analyzed as previously described.

Field experiments were done to assess the effectivity of the mycorrhization with selected fungal strains on the field establishment and performance of olive trees.

Field EXPERIMENT 1. The objective of this trial was to assess the long-term effect of prior-inoculation of young olive plants with $G$. mosseae and $G$. intraradices in a field plantation.

Rooted cuttings of 'Arbequina ' plants, obtained from Agromillora Catalana SA, were transplanted from 100-mL containers to $1000-\mathrm{mL}$ polyethylene bags filled with a compost-based potting mix. The plants were inoculated, using $25 \mathrm{~mL}$ of AMF soil inoculum per plant dispensed as a fine layer below the plant roots. The plants were kept in an open-air nursery for 11 months prior to transplanting into the field.

The field was located in a commercial plantation in northeast Spain, with a semi-arid climate. The characteristics of the soil are summarized in Table 1.

The layout of the experiment was a randomized block design with five blocks of 20 plants per treatment with a hedgerow outline $(3 \times 5 \mathrm{~m})$ with drip fertigation. The treatments were noninoculated control, inoculated with $G$. mosseae and inoculated with $G$. intraradices. During the time course of the experiment, over 3 years, plants were clipped to obtain a plantation suited to mechanical harvest. The growth of the plants was periodically assessed during 41 months from the inoculation to the first harvest. The colonization potential of native AMF in the field soil was determined immediately before the establishment of the plants using a dilution bioassay (Porter, 1979).

At transplanting the percentage of roots colonized by AMF was measured. One, 6, 11, 19, 25, and 30 months after transplant the plant maximum height and the stem diameter were recorded.

In the spring of the first and second year after transplant (11 and 25 months after the inoculation) the macro (N, P, K) and microelements $(\mathrm{Ca}, \mathrm{Fe}, \mathrm{Mn}, \mathrm{Zn})$ in foliar tissue were analyzed. A composite sample was taken from each block, made from 50 fully expanded leaves, from the middle of, nonbearing, current season, shoots. Leaves were thoroughly washed in mild detergent then rinsed twice in distilled water. Samples from each block were divided into two batches; one was used for nitrogen analysis and the other one for the rest of the elements. Nitrogen content was determined

Table 1. Analytical characteristics of the soils from the field experiments.

\begin{tabular}{lcc}
\hline & $\begin{array}{c}\text { Soil from } \\
\text { field Expt. 1 } \\
\text { (Sastago, Zaragoza) }\end{array}$ & $\begin{array}{c}\text { Soil from } \\
\text { field Expt. 2 } \\
\text { (Reus, Tarragona) }\end{array}$ \\
\hline $\mathrm{pH}$ ( in water 1: 2.5) & 7.9 & 8.2 \\
$\mathrm{EC} \mathrm{(at} \mathrm{25} 5^{\circ}$, in water 1:5) & $0.76 \mathrm{dS} \cdot \mathrm{m}^{-1}$ & $0.15 \mathrm{dS} \cdot \mathrm{m}^{-1}$ \\
Organic matter & $3.3 \%(\mathrm{w} / \mathrm{w})$ & $5.4 \%(\mathrm{w} / \mathrm{w})$ \\
$\mathrm{P}($ Olsen) & $17 \mu \mathrm{g} \cdot \mathrm{g}^{-1}$ & $5 \mu \mathrm{g} \cdot \mathrm{g}^{-1}$ \\
$\mathrm{~N}($ Kjeldahl) & $0.2 \%(\mathrm{w} / \mathrm{w})$ & $0.08 \%(\mathrm{w} / \mathrm{w})$ \\
$\mathrm{K}$ & $153 \mu \mathrm{g} \cdot \mathrm{g}^{-1}$ & $166 \mu \mathrm{g} \cdot \mathrm{g}^{-1}$ \\
$\mathrm{CaCO}_{3}$ & $39 \%(\mathrm{w} / \mathrm{w})$ & $16(\mathrm{w} / \mathrm{w})$ \\
\hline
\end{tabular}


Table 2. Nursery experiment 1: Univariate repeated measures analysis for 'Arbequina' olive plants height.

\begin{tabular}{llrrrr}
\hline & Source & df & MS & F & $P$ \\
\hline Between subjects & Treatments & 2 & 13808.087 & 33.957 & 0.000 \\
Within subjects & Error & 27 & 406.637 & & \\
& Time & 4 & 12793.460 & 41.212 & 0.000 \\
& Time $\times$ treatment & 8 & 2169.645 & 6.989 & 0.000 \\
& Error & 108 & 310.428 & & 0.000 \\
& & & & \\
\hline
\end{tabular}

zP values adjusted by the G-G epsilon: 0.5987 .

according to Kjeldahl procedure (Rund, 1984). The remaining samples were dehydrated in an oven at $70^{\circ} \mathrm{C} \pm 1$ for $48 \mathrm{~h}$, ground in a ball mill and digested in wet acid (Jones et al, 1991) using nitric and perchloric acid. Element determination was made with an F586-587 Varian Liberty 220 inductively coupled plasma (ICP) emission spectrometer (Munter and Grande, 1981). At transplanting and after 6 and 25 months growth in the field, root samples were collected and root colonisation by AMF determined. After 30 months growth in the field (41 months after the inoculation) the first olive crop was harvested. The harvest was done manually and the production of each tree was weighed individually. Results were analyzed by a repeated measures analysis of variance (Systat). A regression analysis of the stem diameter measurements, with time as the independent variable, was done to determine the existence of differences between treatments in the rate of growth of the trees.

Field EXPERIMENT 2. This experiment was carried out to assess the response in plant development of 'Arbequina' olive trees to field inoculation with AMF at the moment of transplant to the orchard. Rooted cuttings were obtained from Agromillora Catalana S.A. The experiment was laid out in three blocks (A, B, and $\mathrm{C}$ ) that took into account the differences, in gradient and sun exposure, in the field available to run the trial. The characteristics of the soil are summarized in Table 1 . Two treatments were considered: $G$. intraradices BEG72 and noninoculated control. The inoculation was done with soil inoculum (AMF colonised roots and rhizosphere soil) from leek pot cultures. In each planting hole, $50 \mathrm{~mL}$ of the inoculum was added under the plant roots. The richness of the inoculum was evaluated using a dilution bioassay (Porter, 1979) and was 1300 propagules/100 mL. Block A had 31 trees per treatment, block B 36 trees per treatment, and block C 43 trees per treatment. The orchard was newly planted with a hedgerow design and drip fertigation. A composite soil sample was taken from each block before planting and the native population of AMF was estimated by the Most Probable Number method ( Porter, 1979)

Six months and 20 months after planting the maximum height and the stem diameter of the trees were measured. Results were analyzed by a two-way analysis of variance, with blocks as one of the factors.

\section{Results}

NURSERY EXPERIMENT 1. The statistical analysis shows (Table 2) that both the treatments and the interaction between treatment and sampling time were significant for the periodic measure- ments of plant height. Therefore we can assume that the rate of growth of the plants was different depending on the treatment applied. Two months after inoculation AMF treated plants had an increased growth compared with noninoculated plants, but this was significant only after 15 months growth (Fig. 1). At harvest (Table 3) some of the control plants had become mycorrhizal from the indigenous population of AMF. The mean value of the percentage root colonization for the control plants was $15 \%$, far below the values recorded for the inoculated plants, $75 \%$ for $G$. mosseae and $80 \%$ for $G$. intraradices. There were no significant differences between the root colonization levels of the two fungi used, nor in the growth stimulation they produced, measured as dry weight. However after 24 months growth, plants inoculated

Fig. 1. Nursery experiment 1: growth of 'Arbequina' olive trees, measured as plant height $(\mathrm{cm})$, inoculated either with Glomus intraradices or G. mosseae compared to noninoculated control plants (Mean \pm SEM).

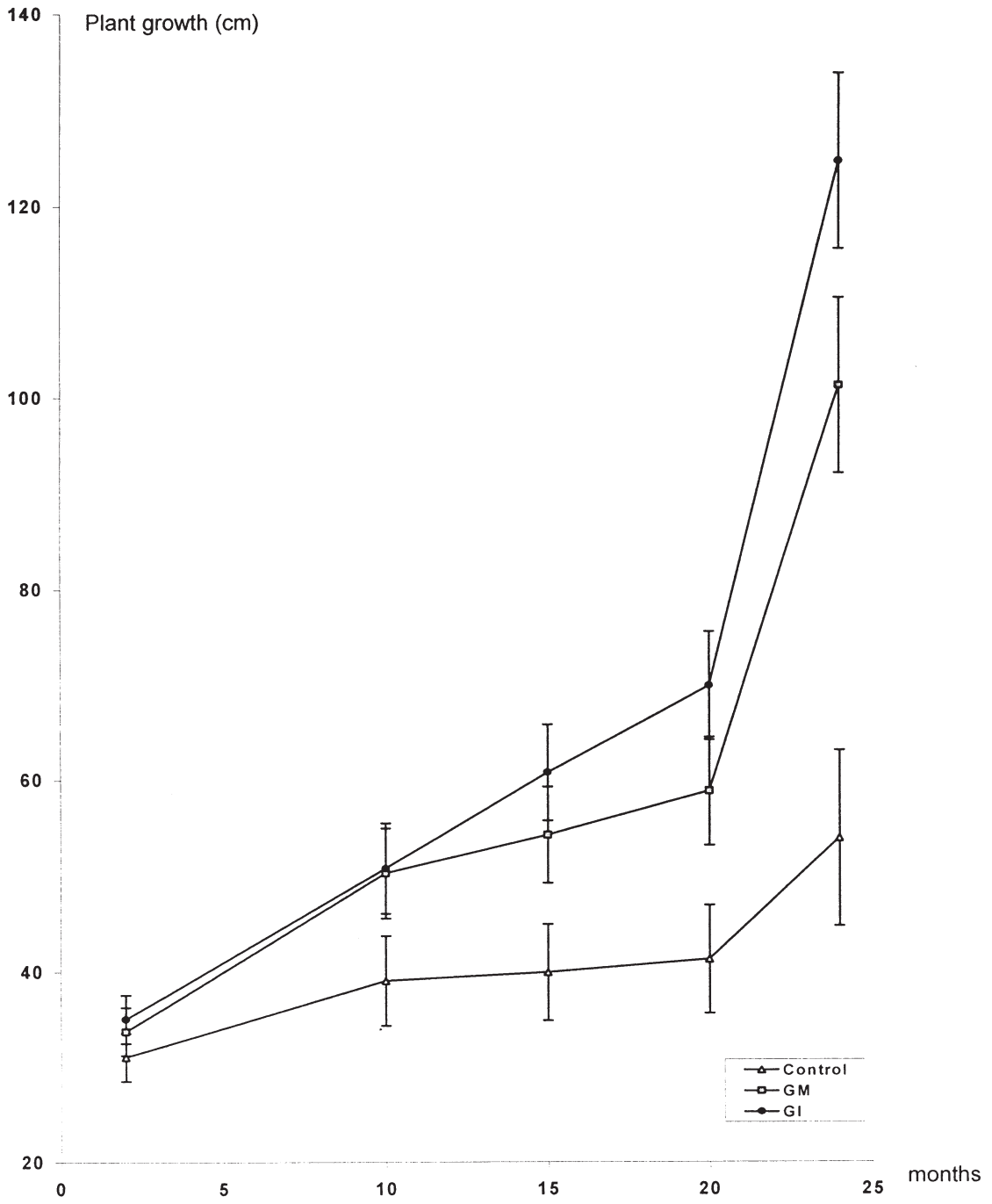


Table 3. Nursery experiment 1: Growth and root colonization of 'Arbequina' olive inoculated with either Glomus intraradices or G. mosseae, compared with the noninoculated control. At harvest, 24 months after inoculation in a sandy soil mix.

\begin{tabular}{|c|c|c|c|c|}
\hline & $\begin{array}{l}\text { Max ht } \\
(\mathrm{cm})\end{array}$ & $\begin{array}{c}\text { Shoot dry } \\
\text { wt (g) }\end{array}$ & $\begin{array}{c}\text { Root dry } \\
\text { wt (g) }\end{array}$ & $\begin{array}{c}\text { Root length } \\
\text { colonized }(\%) \text { y }\end{array}$ \\
\hline G. intraradices & $125 \mathrm{a}$ & $17.9 \mathrm{a}$ & $11.5 \mathrm{a}$ & $75 \mathrm{a}$ \\
\hline
\end{tabular}

zData are means of 10 replications. Means in the same column followed by the same letter do not differ according to Tukey's test of multiple comparisons $(P \leq 0.05)$.

yActual data are presented for percentage of colonization by AMF but data were arcsin transformed for analysis..

Table 4. Nursery experiment 2: Growth parameters and root colonization of ‘Arbequina' olive inoculated with either Glomus intraradices or G. mosseae, and a combination of both delivered as alginate films in a peat-based potting media at two different sampling times.

\begin{tabular}{|c|c|c|c|c|c|}
\hline & $\begin{array}{l}\text { Total shoot } \\
\text { growth }(\mathrm{cm}) \\
(4 \text { months } \\
\text { after inoculation })\end{array}$ & $\begin{array}{c}\text { Max ht }(\mathrm{cm}) \\
\quad(4 \text { months } \\
\text { after inoculation) }\end{array}$ & $\begin{array}{c}\text { Max ht }(\mathrm{cm}) \\
(15 \text { months } \\
\text { after inoculation) }\end{array}$ & $\begin{array}{l}\text { Stem diam }(\mathrm{cm}) \\
\quad(15 \text { months } \\
\text { after inoculation })\end{array}$ & $\begin{array}{c}\text { Root length } \\
\text { colonized }(\%) \\
(15 \text { months } \\
\text { after inoculation) }\end{array}$ \\
\hline P-amended control & $111 \mathrm{a}$ & $57 \mathrm{a}$ & $83 a b$ & $5.10 \mathrm{ab}$ & $7 \mathrm{~b}$ \\
\hline G. intraradices & $103 \mathrm{a}$ & $61 \mathrm{a}$ & 99 a & $5.38 \mathrm{a}$ & $64 \mathrm{a}$ \\
\hline G. mosseae & $105 \mathrm{a}$ & $58 \mathrm{a}$ & $86 a b$ & $4.7 \mathrm{~b}$ & $48 \mathrm{a}$ \\
\hline
\end{tabular}

${ }^{\mathrm{x}}$ Data are mean of 10 replications. Means in the same column followed by the same letter do not differ according to Tukey's test of multiple comparisons $(P \leq 0.05)$.

y Actual data are presented for percentage of AM colonization but data was arcsine transformed for analysis.

Table 5. Field experiment 1: Univariate repeated measures analysis for 'Arbequina' plant height.

\begin{tabular}{llrrrrr}
\hline & Source & df & MS & F & $P$ & G-G $^{z}$ \\
\hline Between subjects & Treatment & 2 & 69334.508 & 33.957 & 0.000 & 0.166 \\
& Block & 4 & 703.246 & 1.634 & \\
Eithin subjects & Error & 287 & 430.452 & & 0.000 \\
& Time & 2 & 79295.533 & 683.172 & 0.021 \\
& Time $\times$ treatment & 4 & 338.500 & 2.916 & 0.000 \\
& Time $\times$ block & 8 & 36.813 & 0.317 & 0.053 \\
& Error & 574 & 116.070 & & &
\end{tabular}

${ }^{\mathrm{z} P}$ values adjusted by the G-G epsilon: 0.5987 .

with $G$. intraradices were taller than plants inoculated with $G$. mosseae (Fig. 1).

NuRSERY EXPERIMENT 2. After 4 months growth there were no differences between treatments when total shoot growth was considered, however the noninoculated, non-P-amended plants had a maximum height significantly lower than the other treatments (Table 4). After 15 months the plants inoculated with $G$. intraradices, alone or combined with G. mosseae, were significantly taller and had thicker stems than the control non-P-amended plants. The inoculation with alginate films in peat was successful in establishing the symbiosis; no significant differences were found in the percentage colonization achieved by the two fungi, alone or in combination, after 15 months growth.

FieLd EXPERIMENT 1. The AMF colonization potential of the five blocks delimited was very similar, and the mean value was 1.49 \pm 0.98 propagules per $100 \mathrm{~mL}$ of soil. This is a very low value for natural soils, probably because of the poor nature of the soil and low indigenous flora, compounded by extensive manipulation, including deep tillage, which was carried out in the orchard to prepare it for cultivation. Despite the low number of propagules found in the soil, after 6 months growth, the noninoculated control plants became mycorrhizal, the percentage colonization was $26 \% \pm 14 \%$, considerably lower than that found for the inoculated trees, with $81 \% \pm 11 \%$ and $76 \% \pm 15 \%$ for G. intraradices and G. mosseae, respectively.

Due to the extensive pruning done 15 and 26 months after transplant to even the plants height to achieve a hedgerow type plantation, only the first three plant height measurements have been considered in the statistical model for plant height (Table 5). One month after transplant olive trees that had been inoculated were taller (Fig. 2) than the noninoculated plants and had a thicker stem diameter (Fig. 3). This experiment was evaluated periodically over 3 years, which enables us to present results of the long-term effectivity of the inoculation treatments with selected AMF. One month after transplant olive trees that had been inoculated were taller and had a thicker stem diameter than the noninoculated plants and this initial difference lasted until the conclusion of the experiment 30 months after transplant and 41 months after inoculation (Figs. 2 and 3). The stem diameter measurements show a highly significant interaction among treatments and time of sampling (Table 6), therefore it is reasonable to conclude that the stem diameter growth curves for the three treatments considered are not parallel (Nemec,1995). In all treatments the increase of the stem diameter fits a linear regression model with the following equations, with t being the time, measured in months:

Stem diameter $(G$. intraradices $)=-9.78+1.34 \mathrm{t}(R=0.88)$

Stem diameter $(G$. mosseae $)=-10.05+1.24 \mathrm{t}(R=0.87)$

Stem diameter $($ Control $)=-12.45+1.23 \mathrm{t}(R=0.87)$ 


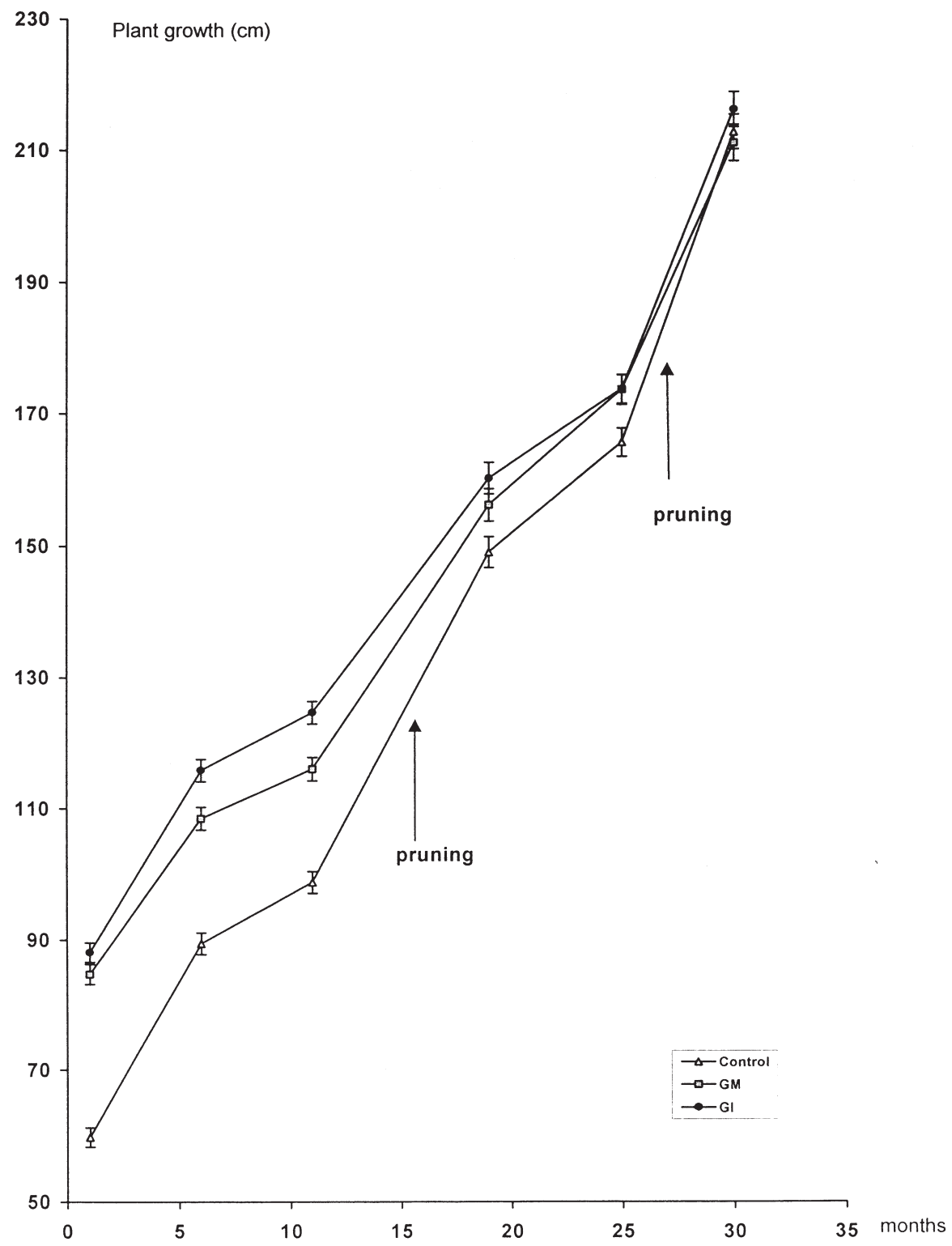

increased the yield of olives, however $G$. intraradices was better than $G$. mosseae at stimulating plant growth and olive crop production.

Field EXPERIMENT 2. The statistical analysis performed (Tables 8 and 9) indicates that the overall effect of the treatments is significant while the block is not. However when analyzing the within the subjects effects and interactions the interaction between sampling time and block is positive for both parameters measured, height and stem diameter, meaning that the plants in the three blocks have different growth rates for these parameters. The block effect can be related to the different natural AMF colonization potential of the three blocks delimited: Block A : 114 propagules/100 mL of soil; block B: 17 propagules $/ 100 \mathrm{~mL}$ of soil; block C: 759 propagules/100 mL of soil. After 6 months growth, the stem diameters of inoculated plants in all blocks were bigger than noninoculated (Fig. 5). After 20 months growth the differences between inoculated and noninoculated plants are apparent only in Block B (Fig. 5), where the initial number of native mycorrhizal propagules was the lowest.

\section{Discussion}

This paper establishes that 'Arbequina' olive trees benefit from artificial inoculation with individual AMF. Roldán-Fajardo and Barea (1986) had shown the mycorrhizal condition of olive trees, and more recently Citernesi et al. (1998) reported a differential growth response of several olive cultivars to inoculation with G. mosseae in greenhouse pot experiments. Rinaldelli and Mancuso (1996) also demonstrated the increased tolerance of young olive plants inoculated with AMF to

Fig. 2. Field experiment 1: growth of 'Arbequina' olive trees, measured as plant height $(\mathrm{cm})$ inoculated either with Glomus intraradices or G. mosseae compared to noninoculated control plants (Mean \pm SEM).

The statistical comparison, two by two, of the three regression lines shows that there is a difference between the values of the intercept of the three lines, and that the value of the slope of the $G$. intraradices treatment is significantly different to the slope values of the $G$. mosseae and control treatments. The variation can be attributed to a differential effect of $G$. intraradices in the rate of growth of the stem diameter compared with $G$. mosseae or the indigenous AMF colonizing the control treatment. The rate of the stem growth is enhanced in the plants inoculated with $G$. intraradices, which could be related to a higher intrinsic efficacy of this fungus. After one year growth in the field, plants inoculated with either $G$. mosseae or G. intraradices had a higher P, K, and $\mathrm{Ca}$ (Table 7) leaf content although all the elements analyzed were within sufficiency levels for olive trees (Jones et al., 1991). After 2 years growth there were no significant differences between the mineral concentrations of inoculated and noninoculated trees.

At harvest (Fig. 4) the results show that both selected AMF salt stress, a soil condition that can be a limiting factor for olive production in many areas of the Mediterranean. The nursery production of crop trees, including olive trees, in containers has increased steadily over the past decade, and pathogen-free soilless mixes are generally used. The roots of these plants are devoid of mycorrhiza when transplanted into field soils, therefore there is an opportunity to establish the symbiosis in these potting media. There have been many attempts to do so with varying results (Biermann and Linderman, 1983; Estaún et al., 1994; Graham, 1984; Menge et al., 1982). Graham and Fardelman (1986) established the AM symbiosis in citrus seedlings in a peat-perlite potting mix and did not find a growth increase when compared with noninoculated seedlings after 4 months growth. Similarly, in our study the differences in total plant growth after 4 months were also nonsignificant, however, after 15 months, olive seedlings inoculated with $G$. intraradices were significantly larger than noninoculated control plants. Graham and Timmer (1985), inoculated citrus seedlings with an isolate of $G$. intraradices, in a peat-perlite mix with rock phosphate as amendment and found that after 5 month growth, the symbiosis was well established and the inoculated plants grew better than the controls. They con- 


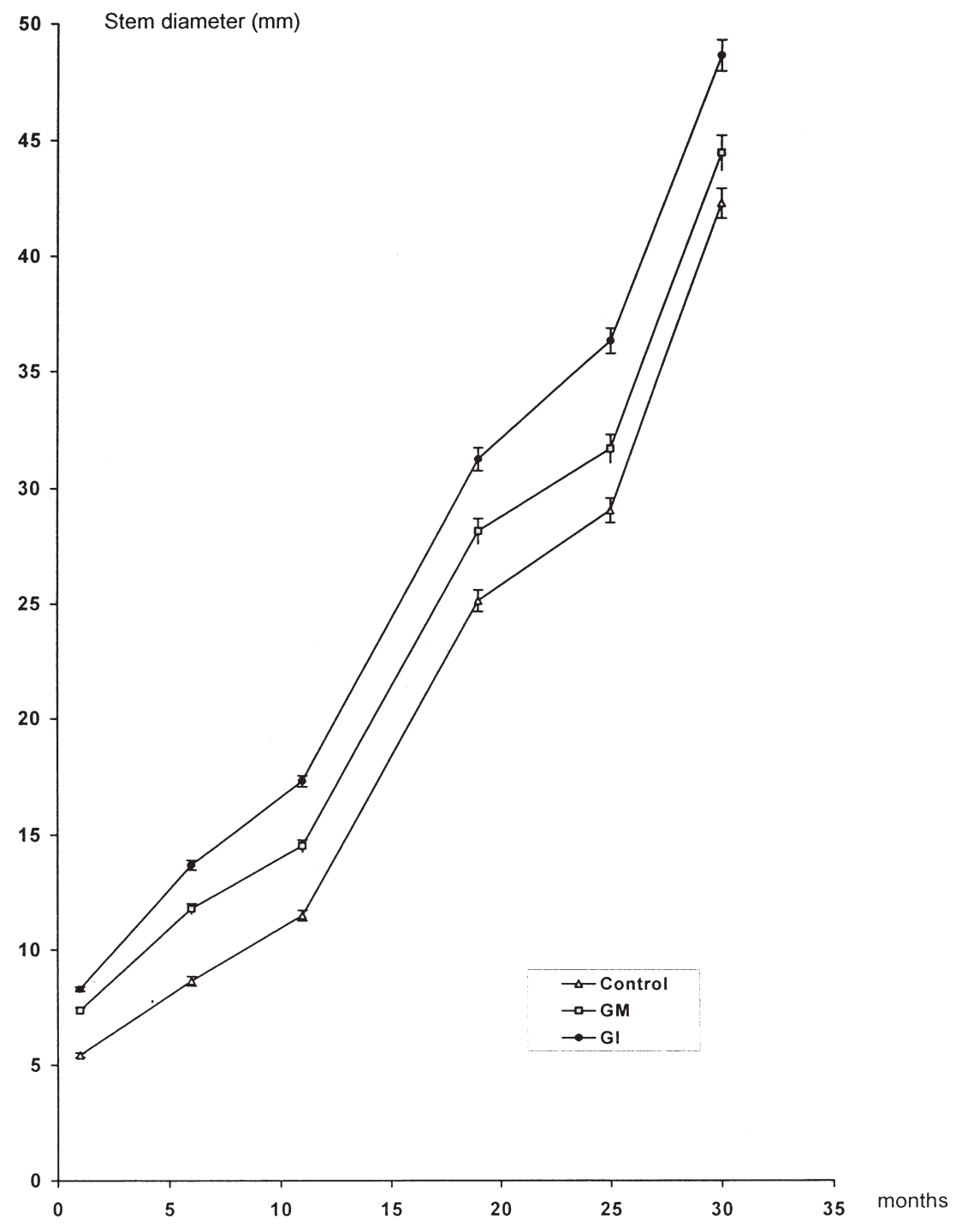

Fig. 3. Field experiment 1: growth of 'Arbequina' olive trees, measured as stem diameter ( $\mathrm{mm}$ ), inoculated either with Glomus intraradices or G. mosseae compared to noninoculated control plants (Mean \pm SEM).

cluded that AM fungi can function as well in high organic media as in mineral soil if $\mathrm{P}$ availability is controlled, although the resulting plant growth did not exceed that of nonmycorrhizal plants in a well fertilized commercial media. Similarly in our experimental conditions, the effect of inoculating with selected AMF was comparable with phosphate fertilization in nursery conditions. In woody plants it is therefore important to conduct studies for a longer time span to allow for the assessment of the long term effects of inoculation. The fact that the symbiosis can be established using soilless organic potting media is essential to promote the integration of this technology into current nursery practices.

In the field experiments, the use of introduced AMF had different outcomes in relation to the inoculation system used and the prevalent soil conditions of the plantation. Inoculation at the time of planting in the field, resulted in an increased growth for the first 6 months, which can be related to a rapid establishment of the symbiosis in the inoculated trees (McGee et al., 1999; Sanders et al., 1977). As the noninoculated control plants develop the symbiosis, the difference in growth diminishes, especially in the areas where the original number of AMF propagules in the soil was high and the onset of the root colonization by native AMF was quick. Inoculation at the time of planting in the field is an advantage in areas where the indigenous AMF population is low, in many instances as a consequence of long periods of fallow followed by heavy tillage (Abbot et al.,1995; McGee at al., 1999; Menéndez et al., 2000).

Table 6. Field experiment 1: Univariate repeated measures analysis for 'Arbequina' stem diameter.

\begin{tabular}{llrrrr}
\hline & Source & df & MS & F & $P$ \\
\hline Between subjects & Treatment & 2 & 3977.137 & 116.698 & 0.000 \\
& Block & 4 & 73.901 & 2.168 & 0.073 \\
Within subjects & Error & 251 & 34.081 & & \\
& Time & 5 & 51736.963 & 4119.678 & 0.000 \\
& Time $\times$ treatment & 10 & 58.578 & 4.664 & 0.000 \\
& Time x block & 20 & 20.27 & 1.595 & 0.046 \\
& Error & 1255 & 12.558 & & 0.000 \\
& & & & \\
\end{tabular}

${ }^{\mathrm{z} P}$ values adjusted by the G-G epsilon: 0.5987 .

Table 7. Field experiment 1: mineral constituents of composite leaf samples from 'Arbequina' olive trees inoculated with either Glomus mosseae or $G$. intraradices, 1 year after transplant in the field.

\begin{tabular}{|c|c|c|c|c|c|c|c|c|c|c|c|c|}
\hline & $\mathrm{N}$ & $\mathrm{P}$ & $\mathrm{K}$ & $\mathrm{Ca}$ & $\mathrm{S}$ & $\mathrm{Mg}$ & $\mathrm{Na}$ & $\mathrm{Fe}$ & $\mathrm{Mn}$ & $\mathrm{Cu}$ & $\mathrm{Zn}$ & $\mathrm{B}$ \\
\hline Treatment & \multicolumn{5}{|c|}{ Dy wt $(\%)$} & & \multicolumn{6}{|c|}{$\mathrm{mg} \cdot \mathrm{kg}^{-1}$} \\
\hline Control & $2.45 \mathrm{a}^{\mathrm{z}}$ & $0.14 \mathrm{~b}$ & $1.05 \mathrm{~b}$ & $1.48 \mathrm{~b}$ & $0.22 \mathrm{~b}$ & $845 \mathrm{a}$ & $377 \mathrm{a}$ & $124 \mathrm{a}$ & $58 \mathrm{a}$ & $8 \mathrm{~b}$ & $23 \mathrm{~b}$ & $25 \mathrm{a}$ \\
\hline G. mosseae & $2.50 \mathrm{a}$ & $0.18 \mathrm{a}$ & $1.11 \mathrm{ab}$ & $1.66 \mathrm{ab}$ & $0.26 \mathrm{a}$ & $936 \mathrm{a}$ & $372 \mathrm{a}$ & $109 \mathrm{ab}$ & $59 \mathrm{a}$ & $9 \mathrm{ab}$ & $30 \mathrm{a}$ & $20 \mathrm{~b}$ \\
\hline Low level & $<1.5$ & $<0.1$ & $<0.5-0.8$ & $<1.0$ & $<0.2$ & --- & --- & --- & $<25$ & --- & $<25$ & $<15-19$ \\
\hline Sufficiency level & $1.5-2.5$ & $0.1-0.3$ & $0.9-1.2$ & 1.0 & $>0.2$ & --- & --- & --- & $>25$ & --- & $>25$ & $20-75$ \\
\hline
\end{tabular}

zValues followed by the same letter in a column do not differ according to Tukey's test of multiple comparisons $(P \leq 0.05)$.

yInterpretative values for foliar analysis in olive (Jones et al., 1991). 


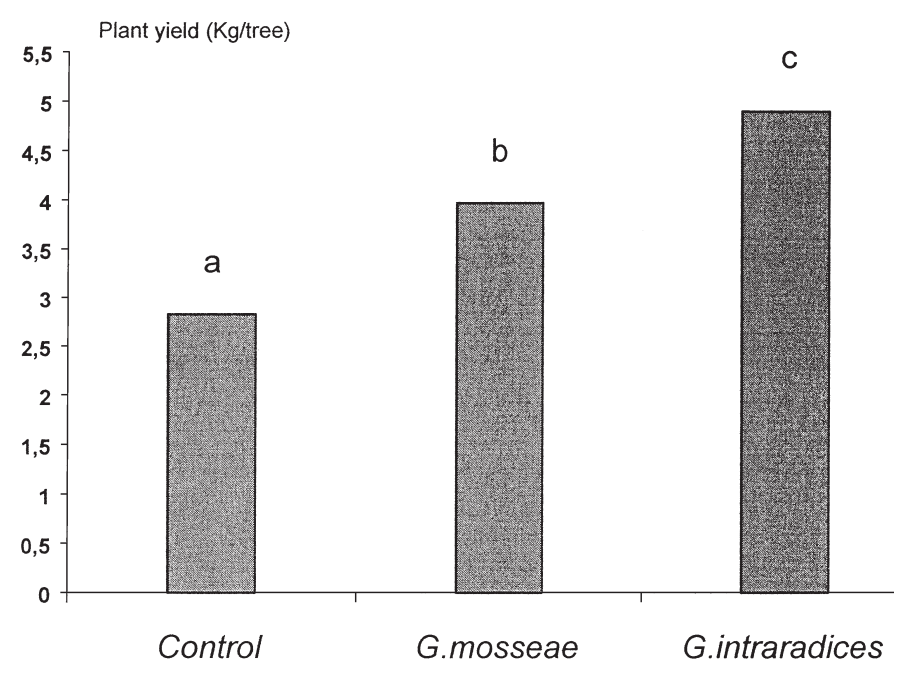

Fig. 4. Field experiment 1: yield of olives by individual 'Arbequina' olive trees, noninoculated control and inoculated with either Glomus intraradices or $G$. mosseae. The data are means of 50 plants. Different letters apply to significant differences among treatments (Tukey's test $P \leq 0.05$ )

crop yield. Distinct AMF have been shown to differ markedly in their ability to improve plant growth of host plants (Clark et al., 1999). In field experiment 1 , the rate of growth shown by olive plants inoculated with G. mosseae was not significantly different from the noninoculated plants colonized by native AMF while plants inoculated with G.intraradices had a higher growth rate than control and G. mosseae inoculated plants. The effects of G. mosseae root colonization in plant development and yield can be attributed mainly to the advantage conferred by the early mycorrhization. An isolate of $G$. intraradices has been shown to hydrolyze organic $\mathrm{P}$ and transport it to host roots (Koide and Kabir, 2000). This could be one of the mechanisms involved in the positive effects on plant growth and crop yield of the isolate

Table 8. Field experiment 2: Univariate repeated measures analysis for 'Arbequina' plant height

\begin{tabular}{|c|c|c|c|c|c|}
\hline & Source & $\mathrm{df}$ & MS & $\mathrm{F}$ & $P$ \\
\hline \multirow[t]{2}{*}{$\overline{\text { Between subjects }}$} & Treatments & 1 & 12479.293 & 30.268 & 0.000 \\
\hline & Error & $180^{z}$ & 412.293 & & \\
\hline \multirow{3}{*}{ Within subjects } & Time $\times$ treatment & 1 & 438.098 & 2.008 & 0.158 \\
\hline & Time $\times$ block & 2 & 2116.702 & 9.703 & 0.000 \\
\hline & Error & 180 & 218.140 & & \\
\hline
\end{tabular}

${ }^{\mathrm{z}}$ Low error df due to a total of 35 missing values (4 to 8 trees in 5 of the 6 plots)

Table 9. Field Expt. 2: Univariate repeated measures analysis for 'Arbequina' stem diameter.

\begin{tabular}{llrrr}
\hline & Source & df & MS & F \\
\hline Between subjects & Treatments & 1 & 463.418 & 33.442 \\
& Block & 2 & 5.647 & 0.407 \\
Within subjects & Error & $180^{z}$ & 13.857 & 0.000 \\
& Time & 1 & 19698.596 & 2769.807 \\
& Time $\times$ treatment & 1 & 38.395 & 5.399 \\
& Time $\times$ block & 2 & 217.954 & 30.646 \\
& Error & 180 & 7.112 & 0.000 \\
\end{tabular}

${ }^{\mathrm{z}}$ Low error df due to a total of 35 missing values (4 to 8 trees in 5 of the 6 plots).

6 months

When plants, in field experiment 1 , were previously inoculated with AMF, before the establishment in the field, the inoculation resulted in a sustained increase in plant growth over the entire length of the 30 months field trial. Katiyar et al. (1995) found that pre-inoculated mulberry trees also produced a sustained plant growth stimulation with one-third of the standard input of fertilizer for a 4-year period. In our experiment the fertilizer input was the same for all plants, nevertheless inoculated plants showed an improved nutrient uptake after one year in the field. There are differences in the efficacy between the two AMF used, G. mosseae and G. intraradices, when used alone, in respect to plant growth and also

Fig. 5. Field experiment 2: Growth 'Arbequina' olive inoculated with Glomus intraradices (striped bars) or noninoculated control (shaded bars). Height (I and II) and stem diameter (III and IV) 6 and 20 months, respectively, after transplanting and inoculation (mean \pm SEM).

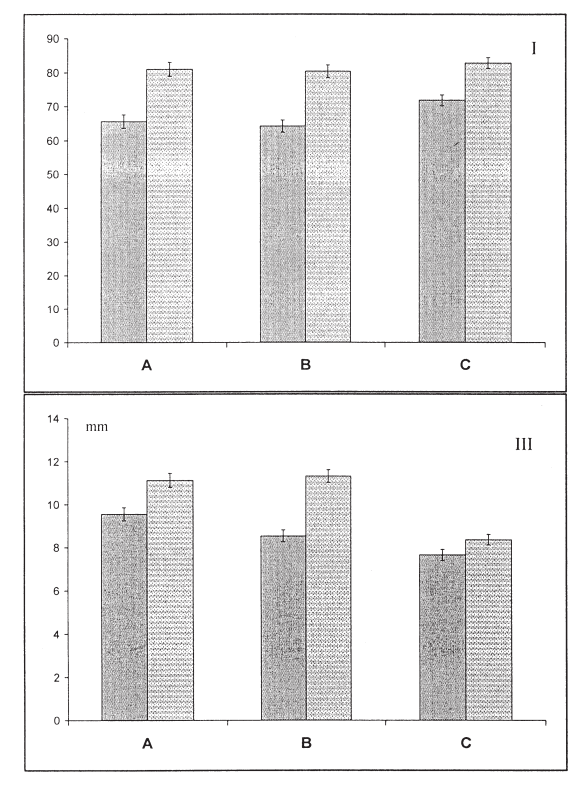

Block
20 months

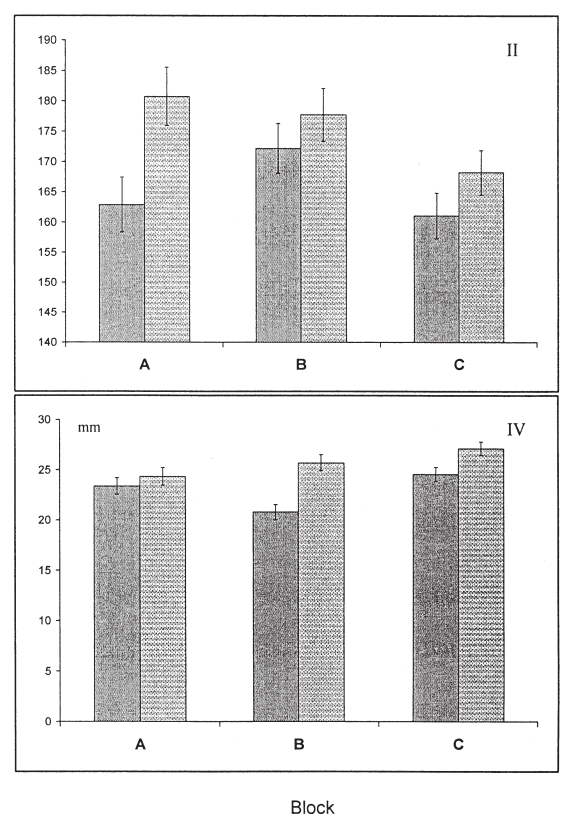


(BEG 72) used in the experiments reported in this paper. Inoculation with selected AMF has been shown to stimulate the yield of crop plants like wheat (Graham and Abbott, 2000; Talukdar and Germida, 1994), rice (Solaiman and Hirata, 1997) and legumes (Bethlenfalvay et al., 1994; Tarafdar and Rao, 1997) with varying results depending on the experimental conditions. However, there are little data in the literature on the use of AMF with fruit trees. Apple trees in a replant situation have been shown to benefit from inoculation with an isolate of $G$. intraradices combined with Enterobacter agglomerans and Bacillus subtilis (Utkhede and Smith, 2000). When pre-inoculated coffee seedlings were taken into a plantation (Siqueira et al., 1998), early plant development and the first bean yield were significantly enhanced. In subsequent years the effects of the precolonization treatments on plant growth and bean yield were reduced. The authors attributed the attenuation of mycorrhizal stimulating effects over time to the colonization of control seedlings by indigenous AMF. In our study, plants inoculated at transplanting followed a similar pattern, with a reduction in the effects of inoculation over time due to the colonization of roots by the indigenous AM fungi. When plants are pre-inoculated and transplanted into an open field soil the growth enhancement conferred by the early establishment of the symbiosis was remarkable and still significant 30 months after transplanting into the orchard. In conclusion the inoculation with both AMF tested, $G$. intraradices BEG72 and G. mosseae BEG116, was effective in promoting early plant development. Olive trees pre-inoculated with selected AMF before transplanting showed long lasting improvement in growth and crop yield. AMF inoculation needs to be considered as a valuable technology for the establishment of olive groves.

\section{Literature Cited}

Abbott, L.K., A.D. Robson, and M.A. Scheltema. 1995. Managing soils to enhance mycorrhizal benefits in Mediterranean agriculture. Crit. Rev. Biotechnol. 15:213-228.

Ba, A.M., C. Plenchette, P.Danthu, R. Duponnois, and T. Guissou. 2000. Functional compatibility of two arbuscular mycorrhizae with thirteen fruit trees in Senegal. Agrofor. Syst. 50(2):95-105

Barker, K.R. 1985. Design of greenhouse and microplot experiments for evaluation of plant resistance to nematodes, p. 107-113. In: B.M. Zuckerman, W.F. Mai, and M.B. Harrison (eds.). Plant nematology laboratory manual. Univ. Mass. Agr. Expt. Sta., Amherst.

Bethlenfalvay, G.J., K.L. Mihara, and R.P. Schreiner. 1994. Mycorrhizae alter protein and lipid content and yield of pea seed. Crop Sci. 34: 998-1003.

Biermann, B.J. and R.G. Linderman.1983. Effect of container plant growth medium and fertilizer phosphorus on establishment and host plant growth response tovesicular-arbuscular mycorrhizae. J. Amer. Soc. Hort. Sci. 108:962-971

Calvet, C., A. Camprubí, and R. Rodríguez-Kábana. 1996. Inclusion of Arbuscular mycorrhizal fungi in alginate films for experimental studies and plant inoculation. HortScience 31:285-286

Camprubí, A. and C. Calvet. 1996. Isolation and screening of mycorrhizal fungi from citrus nurseries and orchards and studies of greenhouse inoculation systems. HortScience 31:366-369

Citernesi, A.S., C. Vitagliano, and M. Giovanetti. 1998. Plant growth and root system morphology of Olea europaea L. rooted cuttings as influenced by arbuscular mycorrhizas. S. J. Hort.Sci. Biotechnol. 73: 647-654

Clark, R.B., S.K. Zeto, and R.W. Zobel.1999. Arbuscular mycorrhizal fungal isolate effectiveness on growth and root colonisation of Panicum virgatum in acidic soils. Soil Biol. Biochem. 31:1757-1763

Dolcet-Sanjuan,R., E. Claveria, A. Camprubí, V. Estaún, and C. Calvet. 1996. Micropropagation of walnut trees (Juglans regia $\mathrm{L}$ ) and response to arbuscular mycorrhizal inoculation. Agronomie 16:639-645

Duffy, E.M. and A.C. Cassells. 2000. The effect of inoculation of potato (Solanum tuberosum L.) microplants with arbusculars mycorrhizal fungi on tuber yield and tuber size distribution. Appl. Soil Ecol. 15: 137-144

Estaún, V., C. Calvet, and A. Camprubí. 1994. Arbuscular mycorrhizae and growth enhancement of micropropagated prunus rootstock in different soilless potting mixes. Agr. Sci. Finland 3:263-267.

Estaún, V., C. Calvet, A. Camprubí, and J. Pinochet.1999. Long term effects of nursery starter substrate and AM inoculation of micropropagated peach x almond hybrid rootstock. Agronomie 19:483-489

Giovanetti, M. and B. Mosse. 1980. An evaluation of techniques for measuring vesicular-arbuscular mycorrhizal infection in roots. New Phytol. 84:489-450.

Graham, J.H. 1984. Application of vesicular-arbuscular mycorrhizal fungi in greenhouse crops: fruits and vegetables, p. 61-68. In: J.J. Ferguson (ed.). Application of mycorrhizal fungi in crop production. Univ. Fla., Gainesville.

Graham,J.H. 1986. Citrus mycorrhizae: Potential benefits and interactions with pathogens HortScience 21:1302-1306

Graham, J.H. and L.K. Abbott.2000. Wheat responses to aggressive and nonaggressive arbuscular mycorrhizal fungi. Plant Soil 220:207-218.

Graham, J.H. and D. Fardelmann. 1986. Inoculation of citrus with root fragments containing chlamydospores of the mycorrhizal fungus Glomus intraradices. Can. J. Bot. 64:1739-1744.

Graham, J.H. and L.W. Timmer. 1985. Rock phosphate as a source of phosphorus for vesicular-arbuscular mycorrhizal development and growth of citrus in a soilless medium. J. Amer. Soc. Hort. Sci. 110:489-492.

Hoagland, D. and D.I. Arnon. 1950. The water culture method for growing plants without soil. Univ. Calif. Agr. Expt. Sta. Circ. 347.

Jones,J.B., W. Benjamin and H.A. Mills.1991. Plant analysis handbook I.Methods of plant analysis and interpretation. Micro-Macro Publishing, Athens, Ga.

Katiyar, R.S., P.K. Das, P.C. Choudhury, A. Ghosh, G.B. Singh, and R.K. Datta. 1995. Response of irrigated mulberry (Morus alba L.) to VA-mycorrhizal inoculation under graded doses of phosphorus. Plant Soil 170:331-337

Koide, R.T. and Z. Kabir. 2000. Extraradical hyphae of the mycorrhizal fungus Glomus intraradices can hydrolyse organic phosphate. New Phytol. 148:511-517.

Koske, R.E. and J.H. Gemma. 1989. A modified procedure for staining roots to detect VA mycorrhizas. Mycol. Res. 92:86-95

McGee, P.A., V. Torrisi, and G.S. Pattinson. 1999. The relationship between density of Glomus mosseae propagules and the initiation and spread of arbusculars mycorrhizas in cotton roots. Mycorrhiza 9:221-225

McGonigle, T.P. 1988 A numerical analysis of published field trials with vesicular-arbuscular mycorrhizal fungi. Funct. Ecol. 2:773-778

Menendez , A.B., J.M. Scervino, and A.M. Godeas. 2001. Arbuscular mycorrhizal populations associated with natural and cultivated vegetation on a site of Buenos Aires province, Argentina. Biol. Fert. Soils 33:373-381

Menge, J.A., W.M. Jarrell, C.K. Labanouskas, J.C. Ojala, C. Huszar, and D. Sibert. 1982. Predicting mycorrhizal dependency of Troyer citrange on Glomus fasciculatus in California citrus soils and nursery mixes. Soil Sci. Soc. Amer. J. 46:762-768

Mosse, B. 1962. The establishment of vesicular-arbuscular mycorrhiza under aseptic conditions. J. Gen. Microbiol. 51: 469-483.

Munter, R.C. and R.A. Grande.1981. Plant tissue and soil extract analysis by ICP-atomic emission spectrometry, p. 653-672. In: R.M.Barnes (ed.). Developments in atomic plasma spectrochemical analysis. Heyden, London.

Nemec, A. and F. Linnell. 1996. Analysis of repeated measures and time series: an introduction with forestry examples. Biom. Inf. Hndbk. 6. Res. Br., B.C. Min. For., Victoria, B.C. Wrk. Pap.15/1996

Phillips, J.M. and D.S. Hayman.1970. Improved procedures for clearing and staining parasitic and vesicular-arbuscular fungi for rapid assessment of infection. Trans. Brit. Mycol. Soc. 55:158-161 
Porter, W.M. 1979. The "most probable number" method for enumerating infective propagules of vesicular-arbuscular mycorrhizal fungi in soil. Austral. J. Soil Res. 17:515-519

Rinaldelli, E. and S. Mancuso. 1996. Response of young mycorrhizal and nonmycorrhizal plants of olive tree (Olea europaea L.) to saline conditions. I Short term electrophysiological and long term vegetative salt effects. Adv. Hort. Sci. 10:126-134.

Roldan-Fajardo, B.E. and J.M. Barea. 1986. Mycorrhizal dependency in the olive tree (Olea europaea. L.), p. 323-326. In: Physiological and genetical aspects of mycorrhizae. Proc. ${ }^{\text {st }}$ Euro. Symp. Mycorrhizae, Dijon, 1985. INRA, Paris.

Rund, R.C. 1984. Fertilizers, p. 8-37. In: S. Williams (ed.). Official methods of analysis of the Association of Official Analytic Chemists. $14^{\text {th }}$ ed. AAOAC, Arlington, Va.

Sanders, F.E., P.B.Tinker, R.L.B. Black, and S.M. Palmerley. 1977. The development of endomycorrhizal root systems. I. Spread of infection and growth promoting effects with four species of vesicular-arbuscular mycorrhizas. New Phytol. 78:257-268.
Siqueira, J.O., O.J. Saggin-Junior, W.W. Flores-Aylas, and P.T.G. Guimaraes. 1998. Arbuscular mycorrhizal inoculation and superphosphate application influence plant development and yield of coffee in Brazil. Mycorrhiza 7:293-300.

Smith, S.E., B.J. St John, F.A. Smith, and J.L Bromley.1986. Effect of mycorrhizal infection on plant growth, nitrogen and phosphorus nutrition of glasshouse grown Allium cepa L. New Phytol. 103:359-373.

Solaiman, N.Z. and H. Hirata. 1997. Effect of arbuscular mycorrhizal fungi inoculation of rice seedlings at the nursery stage upon performance in the paddy field and greenhouse. Plant Soil 191:1-12.

Talukdar, N.C. and J.J.Germida. 1994. Growth and yield of lentil and wheat inoculated with 3 Glomus isolates from Saskatchewan soils. Mycorrhiza 5:145-152

Tarafdar, J.C. and A.V. Rao.1997. Response of arid legumes to VAM inoculation. Symbiosis 22:265-274.

Utkhede, R.S. and E.M. Smith. 2000. Impact of chemical biological and cultural treatments on the growth and yield of apple in replant-disease soil. Australasian Plant Pathol. 29:129-136. 